УДК 314.17

DOI https://doi.org/10.32849/2663-5313/2020.4.67

Олена Поліванова,

канд. юрид.наук,

доцент кафедри міжнародного права і порівняльного правознавства

Київського університету права Національної академії наук Украйни

\title{
ПРОЦЕС ПРИЄДНАННЯ ЄВРОПЕЙСЬКОГО СОЮЗУ ДО ЄВРОПЕЙСЬКОЇ КОНВЕНЦІЇ 3 ПРАВ ЛЮДИНИ ПІСЛЯ ВИСНОВКУ 2/13
}

У статті досліджується прочес приєднання Європейського Союзу до Конвениій про захист прав людини і основоположних свобод 1950 року, здійснюваний інституиійним механізмом Свропейського Союзу і Радою Свропи після винесення Судом Справедливості Європейського Союзу Висновку 2/13 від 18 грудня 2014 року щодо сумісності Проєкту угоди про приєднання Європейського Союзу до Конвениії про захист прав людини і основоположних свобод із Договором про Європейський Союз і Договором про функиіонування Європейського Союзу.

Будучи у баченні Європейського Парламенту подальшим кроком у прочесі європейської інтеграчії, приєднання ЄС до Конвениії не було включено до пріоритетів Комісії ЄС Юнкера. Свропейський Парламент усе ж продовжив відстоювати важливість приєднання і 20 квітня 2016 року його Комітет з конституиійних питань організував громадські слухання щодо приєднання ЄС до Конвениії і підбиття підсумків за висновком Суду СС, щоб вивчити способи та засоби відновлення прочесу приєднання. Разом із тим відсутність приєднання ЄС до Конвениії серед пріоритетних напрямів діяльності Комісіі ЄС, ігнорування теми приєднання у програмах Комісії ЄС на 2018-2020 роки, зусилля ЄС на шляху до імплементації Хартії основних прав ЕС у інституційний механізм ЄС ставлять актуальність для ЄС його приєднання до Конвениї про захист прав людини і основоположних свобод під питання.

Проаналізувавши акти інституиійного механізму Європейського Союзу (Комісії $\epsilon С$ i Європейського Парламенту), у яких зачіпалося питання приєднання Європейського Союзу до Конвениії, за період з 2016 по 2020 роки, зроблено висновок, що немає підстав ані заперечувати актуальність для ЄС приєднання до Конвенції, ані стверджувати його активне зачікавлення у реалізації приєднання. 3 одного боку, акти інституиійного механізму ЄС (Комісії ЄС і ЄП) продовжують містити положення щодо важливості і пріоритетності приєднання ЄС до Конвенціі, з іншого - процес вироблення правових інструментів встановлення моделей приєднання ЄС до Конвениії виглядає явно затягнутим, що не може не наштовхувати на думку щодо зміщення пріоритетів ЄС у сфері захисту прав людини - з об'єднання наявних систем ЄС $i$ Ради Європи на утвердження системи захисту прав людини ЄС і посилення у иій системі ролі Хартії основних прав $Е С$.

Ключові слова: Європейський Союз, Конвенція про захист прав людини і основоположних свобод, Висновок 2/13, приєднання, Комісія ЄС, Європейський Парламент, Хартія основних прав Європейського Союзу.

Постановка проблеми. 15 січня 2020 року заступники міністрів Ради Свропи ухвалили продовження термінів співпраці із представниками $\mathrm{CC}$ y ad hoc групі щодо вироблення правових інструментів встановлення моделей приєднання Європейського Союзу (далі - СС) до Конвенції про захист прав людини і основоположних свобод 1950 року [8] (далі - Свропейська конвенція з прав людини, СКПЛ, Конвенція). Такому рішенню передував лист від 31 листопада 2019 року, підписаний як Президентом, так і Першим віце-президентом Комісії ЄC, яким Генеральний Секретар Ради Європи була інформована про те, що ЄС залишається готовим відновити переговори щодо приєд- нання до Конвенції. Разом із тим після винесення Судом справедливості ЄС (далі - Суд ЄC) Висновку 2/13 щодо сумісності Проєкту угоди про приєднання ЄС до СКПЛ із Договором про ЄС (далі - ДЄС) і Договором про функціонування ЄС (далі - ДФСС) (далі Висновок 2/13) не на користь приєднання [14], саме приєднання тільки і обмежується «переговорами і твердженнями» як з боку Комісії СС і Європейського Парламенту (далі - ЄП), так і з боку уповноважених у вирішенні цього питання представників Ради Європи, що і зумовлює актуальність і необхідність здійсненого дослідження.

Аналіз останніх досліджень і публікацій. Окремим аспектам приєднання ЄС до ЄКПЛ 
(зокрема, впливу приєднання на структуру судових органів у Європі, обгрунтуванню позиції Суду ЄС щодо приєднання, розгляду перешкод приєднання, аналізу самого Висновку 2/13) були присвячені дослідження як українських (Т.В. Комарової, О.В. Сердюка, Л.Г. Фалалєєвої ), так і зарубіжних науковців (Р. Арнольд, С.П. Добрянського, С. Дуглас-Скотт, К. Екес, Дж. Заккароні, Ф. Кореніка, М. Куйера, Дж. Одермата). Разом із тим у науковій доктрині практично відсутні дослідження сучасного стану реалізації приєднання СС до Конвенції, а саме періоду з моменту винесення сумнозвісного Висновку 2/13 і дотепер. Тому у статті зроблено спробу розглянути кроки у напрямі реалізації приєднання, здійснені інституційним механізмом СС саме у цей період, і заповнити відповідну прогалину української науки європейського права.

Метою статті $€$ аналіз процесу приєднання СC до Конвенції на сучасному етапі з моменту винесення Висновку 2/13.

Виклад основного матеріалу. Після завершення підготовки Проєкту угоди щодо приєднання Європейського Союзу до Конвенції про захист прав людини і основоположних свобод 1950 року (далі - Проєкт угоди, Угода) Комісія ЄС відповідно до наявних у неї повноважень у рамках ст. 218 ДФЄС звернулася до Суду ЄС із запитом надати консультативний висновок щодо того, чи сумісний Проєкт угоди з установчими договорами ЄС (п. 1 Висновку 2/13) [14]. У своєму Висновку 2/13 від 18 грудня 2014 року Суд $С$ С зазначив, що Проєкт угоди не сумісний ні $з$ п. 2 ст. 6 ДЄС, ні з Протоколом 8 « Сосовно пункту 2 статті 6 Договору про Свропейський Союз щодо приєднання до Європейської Конвенції щодо захисту прав людини і основоположних свобод» [14]. Свою позицію Суд СС аргументував у п. 258, зазначивши, що Угода «може негативно вплинути на специфічні характеристики та автономію права $\mathrm{CC}$, оскільки вона не передбачає координацію між Статтею 53 СКПЛ та Статтею 53 Хартії, не запобігає ризику, що принцип взаємної довіри держав-членів відповідно до права ЄС може бути підірваний, не містить положень стосовно взаємодії між механізмом, встановленим Протоколом 16, та процедурою винесення попереднього рішення, передбаченою статтею 267 ДФЕС...» [14]. Також Суд СС зауважив, що Угода може вплинути на ст. 344 ДФСС, оскільки не $€$ винятком, що суперечки можуть виникнути між державами-членами або між державою-членом та ЄС щодо застосування ЄКПЛ у межах сфери застосування права СC ratione materiae, яке підлягатиме оскарженню в ЄСПЛ (ч. 2 п. 258 Висновку 2/13) [14]. Крім того, у баченні Суду СС Угода не містить положень щодо функціонування механізму співвідповідача та порядку попереднього залучення Суду СС, які б дали змогу зберегти специфічні характеристики права $\mathrm{CC}$ та самого $\mathcal{~} \mathrm{C}$, не враховує особливості права СС щодо судового перегляду актів, заходів чи бездіяльності з боку ЄС у питаннях Спільної зовнішньої політики і політики безпеки СС (далі - СЗППБ), позаяк вона делегує судовий перегляд деяких із таких актів, заходів чи бездіяльності виключно «не СС органу» (ч. 3-4 п. 258 Висновку 2/13) [14].

Разом із тим навіть після Висновку 2/13 ЄП не полишив питання реалізації приєднання. У його баченні приєднання ЄС до ЄКПЛ стане подальшим кроком у процесі європейської інтеграції та надішле сильний сигнал щодо узгодженості між EC та системою прав людини Ради Європи [5]. Тому 16 вересня 2015 року ЄП прийняв резолюцію про підготовку Робочої програми Комісії СС на 2016 рік, у якій «заохотив» Комісію $\mathrm{CC} \mathrm{«просувати} \mathrm{приєднання} \mathrm{CC} \mathrm{до}$ ЄКПЛ та вирішити інші правові виклики, враховуючи думку Суду», а також закликав цю інституцію активізувати зусилля для забезпечення приєднання [9]. Водночас тема приєднання ЄС до ЄКПЛ не була зазначена серед 10 пріоритетів Комісії СС Юнкера. На це звернув увагу і $Є П$ у вищезгаданій резолюції [9; 3, с. 30].

ЄП усе ж продовжив відстоювати важливість приєднання і 20 квітня 2016 року Комітет ЄП з конституційних питань (далі - ККП) організував громадські слухання на тему «Приєднання до Європейської Конвенції з прав людини (СКПЛ): підбиття підсумків за висновком Суду СС та шлях уперед», щоб вивчити способи та засоби відновлення процесу приєднання [17]. Виступаючи від імені Юридичної служби Ради Європи, проф. Йорг Полакевич зазначив, що є потреба вирішувати заперечення Суду СС по черзі, приймаючи такі рішення щодо їх усунення, які відповідають як вимогам конституційного права ЄС, так і цілісності системи ЄКПЛ, а потім переподати нову угоду про приєднання до Суду ЄC (§ 46) [15, с. 16]. 3 боку ЄC проф. Жан Пол Жакке наголосив, що основні права в $С \mathrm{C}$ не $є$ у небезпеці, і що Суд $\mathrm{CC}$ після винесення ним Висновку $2 / 13$ безумовно, буде ще більш пильним у забезпеченні їхньої поваги з боку інституцій $\mathrm{CC}$ [12]. Двоє вчених д-р Соня Морано-Фоаді (Університет Оксфорд Брукс) та д-р Стеліос Андреадакіс (Університет Лестера) 
також висловили свою думку з цього приводу [17]. Зокрема, для вирішення проблеми несумісності ст. 53 Хартії основних прав ЄС (далі - Хартія) і ст. 53 ЄКПЛ, виявленої Судом СС у його Висновку $2 / 13$, ними було запропоновано три можливі рішення. Перше - прийняти тлумачну декларацію як додаток до Угоди (може бути прийнято окремий меморандум про взаєморозуміння з положенням, що ст. 53 СКПЛ не дає права Договірним Сторонам застосовувати більш високі стандарти захисту основних прав таким чином, щоб це могло поставити під загрозу захист, встановлений Хартією, або першість, єдність чи ефективність права (C). Друге рішення - внести доповнення до Угоди у формі додаткової статті (додаткове положення може бути включено безпосередньо до Угоди і роз'яснити взаємозв'язок між ст.ст. 53 ЄКПЛ та 53 Хартії у встановленні стандартів захисту основних прав). Трете рішення проблеми несумісності положень ст. 53 ЄКПЛ і ст. 53 Хартії, запропоноване науковцями, - внести зміни до обох статей (обидві статті можуть бути змінені таким чином, щоб їхні тексти були більш узгодженими і чіткіше виражали зміст, який вони тлумачать) [17, с. 4].

Щодо Протоколу 16 до Конвенції і консультативної юрисдикції ЄСПЛ також були запропоновані два рішення. Перше полягало у включенні до Угоди положення, згідно з яким суди держав-членів $\mathrm{CC}$ мають утримуватися від запитів щодо консультативних висновків ЄСПЛ щодо тлумачення, застосування та обгрунтованості права $\mathrm{CC}$, а натомість, повинні передати це питання до Суду СC у порядку процедури попереднього рішення відповідно до ст. 267 ДФЄС. Цей варіант пропонувався для подолання будьякого проблемного питання, пов'язаного 3 автономією СС і роллю Суду СС у правопорядку СС. У рамках другого рішення держави-члени $\mathrm{CC}$ мають взяти на себе зобов'язання, що вони не підписуватимуть і не ратифіковуватимуть Протокол 16 до Конвенції [17, с. 5].

Для вирішення проблеми напруженості в рамках ст. 344 ДФСС, відзначеної у Висновку 2/13 Судом СС, були передбачені такі альтернативи: а) прийняти в рамках Угоди положення про чітке виключення компетенції ЄСПЛ відповідно до ст. 33 ЄКПЛ зі спорів між державами-членами СС або між державами-членами $\mathrm{CC}$ і $€ \mathrm{C} 3$ питань, що стосуються застосування СКПЛ у межах сфери застосування права ЄC ratione materiae чи б) попросити держави-члени $\mathrm{CC}$ перед приєднанням розробити зобов'язальну декларацію відповідно до міжнародного права про те, що вони не будуть ініціювати провадження або брати участь у провадженні за статтею 33 ЄКПЛ, якщо об'єкт спору підпадає під матеріальне поле права СС [17, с. 5].

У рамках проблемного питання щодо механізму співвідповідача і залучення та розподілу відповідальності, вказаного у Висновку 2/13 Судом $\mathrm{CC}$, у рамках громадських слухань були запропоновані такі пропозиції його вирішення. Стосовно залучення вважається доцільним переглянути п. 5 ст. 3 Проєкту угоди, щоб гарантувати $\mathrm{CC}$ чи державічлену ЄС статус співвідповідача на іхній запит без будь-якої форми перегляду ССПЛ. Щодо розподілу відповідальності пропонується переглянути п. 7 ст. 3 Проєкту угоди, виключивши частину положення, у якому ЄСПЛ може вирішувати, як виняток із норми про спільну відповідальність, що тільки один співвідповідач несе відповідальність. Доречним визначається також подальше внесення ясності у п. 7 ст. 3 Проєкту угоди стосовно застережень, зроблених державою-членом $\mathrm{CC}$, відповідно до якого держава-член $\mathrm{CC}$ не може нести відповідальність ні як відповідач, ні як співвідповідач, виходячи із наявності такого застереження [17, с. 6$]$.

Питанню попереднього залучення Суду СC також було приділено увагу і запропоновано три альтернативи його врегулювання, які не є взаємовиключними і можуть бути об'єднані у процесі перегляду Проєкту угоди: а) включити до Угоди конкретне і чітке положення про те, що ЄСПЛ «має припинити провадження у справі, якщо $\mathrm{CC}$ як співвідповідач повідомить його про те, що у справу буде залучений Суд $\mathrm{CC»,} \mathrm{б)} \mathrm{додати}$ роз'яснення в Проєкт угоди, щоб усунути ризик прийняття ЄСПЛ рішення щодо прийнятності попередньої участі у випадках, коли Суд СС ще не тлумачив спірне право $\mathrm{EC}$, яке розглядається, в) включити у Проєкт угоди положення, що вимагає від ЄСПЛ повністю та систематично інформувати СС про будь-яку справу на розгляді ЄСПЛ, у якій ЄС може потенційно бути співвідповідачем [17, с. 6].

У контексті СЗППБ СС та простору свободи, безпеки і юстиції ЄС (ПСБЮ СC) були обговорені декілька правових рішень. Зокрема, ЄС може зробити застереження до ЄКПЛ, виключивши СЗППБ ЄС та СПБЮ ЄС з юрисдикції ЄСПЛ, підписуючи або висловлюючи свою згоду на обов'язковість положень Угоди відповідно до їі статті 10 (цей варіант не буде вимагати внесення змін до Угоди). 3 іншого боку, можливе і внесення змін до Проєкту угоди, щоб включити положення, яке виключає СЗППБ ЄС та СПБЮ ЄС з юрисдикції ЄСПЛ, 
та додати положення, що роз'яснюють сферу дії принципу взаємної довіри. Разом із тим не виключається і варіант внесення змін до первинного права $\mathrm{CC}$, щоб розширити юрисдикцію Суду ЄС щодо СЗППБ ЄС та уточнити сферу застосування принципу взаємної довіри стосовно СПБЮ ЄС [17, с. 6-7].

Як бачимо, за ініціативою СП провідні європейські науковці запропонували низку раціональних варіантів вдосконалення змісту Угоди із тим, щоб усунути встановлену Судом СС іiі невідповідність установчим договорам $\mathrm{CC}$. Разом із тим оновленого тексту Угоди, узгодженого СС і Радою Європи, тоді підготовлено не було. ККП підтвердив своє зобов'язання продовжувати роботу з приєднання до ЄКПЛ у своєму «Висновку Комітету з питань громадянських свобод, юстиції та внутрішніх справ по ситуації з основними правами у СС у 2015 році» від 9 листопада 2016 року, у якому $Є П$ пропонує Комісії ЄС визначити необхідні кроки для реалізації приєднання. Більше того, 13 грудня 2016 року ЄП прийняв резолюцію про стан основних прав у СС у 2015 році (доповідач - Крістіан Дан Преда, парламентар від Румунії) [10]. У резолюції ЄП наголосив, що приєднання ЄС до ЄКПЛ є зобов'язанням СС за п. 2 ст. 6 Договору про $\mathrm{CC} \mathrm{i,} \mathrm{відповідно,} \mathrm{приєднання} \mathrm{посилить}$ захист основних прав у ЄС (п. 4 резолюції) [10]. Разом із тим ЄП висловив сподівання, що «юридичні перешкоди» приєднання СС до Конвенції будуть «усунені якнайшвидше» (п. 4 резолюції) [10].

Водночас Комісія СС, «оговтавшись» від критики Суду ЄС Проєкту угоди, у свої Робочій програмі на 2016 рік оголосила, що вона продовжить роботу над приєднанням, беручи повною мірою до уваги висновки Суду ЄС з цього приводу [13, с. 10]. Це твердження було відтворене практично у тому ж формулюванні у Робочій програмі Комісії ЄC 2017 року [6, с. 12]. У травні ж 2017 року у своєму Робочому документі щодо застосування Хартії основних прав ЄС у 2016 році Комісія СС відзначила, що Лісабонський договір 2007 року поклав на ЄС зобов'язання приєднатися до Конвенції, тому приєднання ЄС до ССПЛ залишається пріоритетним завданням Комісії СC [4, с. 4; 5]. Автори документа вважають, що таке приєднання «покращить ефективність права СС та посилить узгодженість захисту основних прав у Свропі».

Разом із тим у Робочій програмі Комісії ЄС на 2018 рік «Порядок денний створення більш об'єднаної, сильнішої та демократичнішої Європи» приєднання ЄС до Конвенції не було включене у число програмних цілей. Натомість у рамках сфери правосуддя та основних прав, заснованій на взаємній довірі [1, с. 7-8], Комісією ЄС було визначено три основні напрями: представлення нової У годи для споживачів з метою посилення судового та позасудового захисту їхніх прав і сприяння координації та ефективним діям національних органів споживачів, посилення механізму ЄС з цивільного захисту із наданням йому власних оперативних можливостей із тим, щоб забезпечити кращу кризову та надзвичайну підтримку громадян ЄC 3 максимальною ефективністю та мінімальним рівнем бюрократії, а також вироблення пропозицій щодо поліпшення транскордонного доступу до електронних доказів та фінансових даних правоохоронним органам та подальшого зміцнення правил протидії вибуховим речовинам, які використовуються терористами для виготовлення саморобної зброї [1, с. 7-8]

Робоча програма Комісії СС на 2019 рік «Виконання того, що ми обіцяли, і підготовка до майбутнього» [7] також не містила посилання на перспективи приєднання $\mathrm{CC}$ до ЄКПЛ. У контексті сфери правосуддя та основних прав, заснованої на взаємній довірі, у програмі було здебільшого обіцяно виконання напрямів, окреслених у Робочій програмі Комісії СС 2018 року.

Разом із тим Резолюція ЄП від 12 лютого 2019 року щодо імплементації Хартії основних прав СС у інституційну структуру СС містила положення щодо важливості приєднання ЄС до СКПЛ [11].

У Робочій програмі Комісії СС на 2020 рік «Союз, який прагне більшого» [2] Комісія СС заявляла, що буде тісно співпрацювати з Радою СС щодо Плану дій з прав людини та демократії, який зосередить увагу на провідній ролі ЄС у встановленні стандартів прав людини та дотриманні міжнародного гуманітарного права. Комісія також запланувала розробити План дій щодо гендерної рівності та розширення можливостей жінок у зовнішніх зносинах [2, с. 7]. Більше того, Комісія СС обіцяла запропонувати нову Стратегію імплементації Хартії з акцентом на підвищення обізнаності на національному рівні [2, с. 8]. Водночас знову приєднання $\mathrm{CC}$ до ЄКПЛ було виключено з предметної бази документа.

Виходячи із продовження термінів співпраці представників Ради Свропи із представниками $\mathrm{EC} \mathrm{y} \mathrm{ad} \mathrm{hoc} \mathrm{групі} \mathrm{щодо} \mathrm{виро-}$ блення правових інструментів встановлення моделей приєднання ЄС до Конвенції, ЄС і Рада Європа все ж продовжують роботу над оновленою версією Угоди. Комісія ЄС (як речник $\mathrm{CC} \mathrm{у} \mathrm{цьому} \mathrm{питанні)} \mathrm{продовжує}$ 
консультуватися 3 відповідною робочою групою Ради Свропи щодо вирішення різноманітних заперечень приєднання, висунутих Судом СС [8].

\section{Висновки}

Виходячи із вищевикладеного, немає підстав як заперечувати актуальність для СС приєднання до Конвенції, так і резюмувати щодо активної зацікавленості СС у його реалізації. 3 одного боку, у актах інституційного механізму ЄС (Комісії ЄС і СП) продовжує стверджуватися важливість приєднання (хоч в останні роки, на наш погляд, менш упевнено), з іншого боку, процес вироблення правових інструментів встановлення моделей приєднання СС до Конвенції виглядає явно затягнутим, що не може не наштовхувати на думки щодо зміщення пріоритетів $\mathrm{CC}$ у сфері захисту прав людини - з об'єднання наявних систем $€ \mathrm{C}$ і Ради Свропи на утвердження системи захисту прав людини СС і посилення у цій системі ролі Хартії основних прав $\mathrm{CC.}$

\section{Список використаних джерел:}

1. An agenda for a more united, stronger and more democratic Europe. Commission Work Programme 2018. Strasbourg, 24.10.2017. URL: https:// ec.europa.eu/info/sites/info/files/cwp_2018_en.pdf (дата звернення: 05.04.2020).

2. A Union that strives for more. Commission Work Programme 2020. Brussels, 29.1.2020. URL: $\quad$ https://eur-lex.europa.eu/resource.htm1 ? uri $=$ cellar\%3 A7 ae642 ea-4340-11 ea-b81b$01 \mathrm{aa} 75 \mathrm{ed} 71 \mathrm{a} 1.0002 .02 / \mathrm{DOC} 1 \&$ format $=$ PDF (дата звернення: 05.04.2020).

3. Bassot É., Hiller W. The Juncker Commission's ten priorities State of play in mid-2016. EPRS. 2016. P. 30.

4. Commission Staff Working Document on the Application of the EU Charter of Fundamental Rights in 2016 accompanying the Communication from the Commission to the European Parliament, the Council, the European Economic and Social Committee and the Committee of the Regions on 2016 Report on the Application of the EU Charter of Fundamental Rights. Brussels, 18.5.2017 SWD (2017). P. 4. URL: https://op.europa.eu/en/publication-detail/-/publication/d74ebf9e-3bae-11e7a08e-01aa75ed71a1/language-en/format-PDF (дата звернення: 01.03.2020)

5. Completion of EU Accession to the ECHR. Legislative Train Schedule Area of Justice and Fundamental Rights. URL: https://www.europarl.europa.eu/ legislative-train/theme-area-of-justice-and-fundamental-rights/file-completion-of-eu-accession-tothe-echr (дата звернення: 01.03.2020).

6. Delivering a Europe that protects, empowers and defends. Commission Work Programme 2017. Strasbourg, 25.10.2016 COM
(2016). P. 12. URL: https://ec.europa.eu/info/ sites/info/files/cwp 2017 en.pdf (дата звернення: 29.02.2020)

7. Delivering what we promised and preparing for the future. Commission Work Programme 2019. Strasbourg, 23.10.2018. URL: https:// eur-lex.europa.eu/resource.html?uri=cellar\%3Ada6e3b4b-d79b-11e8-90c0-01aa75ed71a1.0001.02/ DOC 1\&format=PDF (дата звернення: 05.04.2020).

8. EU accession to the ECHR. Human rights intergovernmental cooperation. Council of Europe. URL: https://www.coe.int/en/web/human-rights-intergovernmental-cooperation/accession-of-the-european-union-to-the-european-convention-on-humanrights (дата звернення: 29.02.2020).

9. European Parliament resolution of 16 September 2015 on the Commission Work Programme 2016 (2015/2729(RSP)). European Parliament. URL: https://www.europarl.europa.eu/doceo/document/TA-8-2015-0323 EN.html?redirect (дата звернення: 01.03.2020).

10. European Parliament resolution of 13 December 2016 on the situation of fundamental rights in the European Union in 2015 (2016/2009(INI)). European Parliament. URL: https://www.europarl. europa.eu/doceo/document/TA-8-2016-0485 EN.html?redirect (дата звернення: 01.03.2020).

11. European Parliament resolution of 12 February 2019 on the implementation of the Charter of Fundamental Rights of the European Union in the EU institutional framework (2017/2089(INI)). European Parliament. URL: https://www.europarl.europa.eu/ doceo/document/TA-8-2019-0079_EN.html (дата звернення: 01.03.2020)

12. Jacqué J.P. L'adhésion à la Convention Européenne des droits de l'homme après l'avis 2/13 de la Cour de justice de l'Union européenne. Affaires Constitutionnelles, Parlement Europeen. URL: https://www.europarl.europa.eu/cmsdata/104501/Briefing 20.04.2016\%20\%282\%29.pdf (дата звернення: 01.03.2020).

13. No time for business as usual. Commission Work Programme 2016. Strasbourg, 27.10.2015 COM (2015). P. 10. URL: https://ec.europa.eu/info/sites/ info/files/cwp 2016 en 0.pdf (дата звернення: 29.02.2020)

14. Opinion 2/13 of the Court (Full Court) on the compatibility of the draft agreement with the EU and FEU Treaties. ECJ, 18 December 2014. EUR-lex, access to the European Union Law. URL: https://eur-lex.europa.eu/legal-content/ $\mathrm{EN} / \mathrm{TXT} /$ ?uri=CELEX\%3A62013CV0002 (дата звернення: 29.02.2020).

15. Polakiewicz J. Accession to the European Convention on Human Rights (ECHR): stocktaking after the ECJ's opinion and way forward. European Parliament, Committee on Constitutional Affairs Public Hearing 20 April 2016. P. 16, para. 46 URL: https://www.europarl.europa.eu/cmsdata/104500/ EP_hearing_20_April_2016_rev.pdf (дата звернення: 01.03.2020).

16. Protocol No. 16 to the Convention on the Protection of Human Rights and Fundamental 
Freedoms. Strasbourg, 2.X.2013. Council of Europe Treaty Series. No. 214. URL: https:// www.echr.coe.int/Documents/Protocol_16_ENG. pdf (дата звернення: 01.03.2020).

17. The EU Accession to the ECHR after Opinion 2/13: Reflections, Solutions and the
Way Forward. Contribution of Dr Sonia Morano-Foadi and Dr Stelios Andreadakis. 20 April 2016. URL: https://www.europarl.europa.eu/cmsdata/104504/Executive\%20Summary\%20MoranoFoadi\%20Andreadakis\%20April\%202016.pdf (дата звернення: 01.03.2020).

The article examines the process of accession of the European Union to the Convention for the Protection of Human Rights and Fundamental Freedoms of 1950, has being implemented by the institutional mechanism of the European Union and the Council of Europe after the Court of Justice of the European Union delivered its Opinion 2/13 of 18 December 2014 on the compatibility of the draft EU Accession Agreement to the Convention for the Protection of Human Rights and Fundamental Freedoms with the Treaty on European Union and the Treaty on the Functioning of the European Union.

Being, in a vision of the European Parliament, a further step in the process of European integration, the EU accession to the Convention was not included into the priorities of the European Commission of Juncker. However, the European Parliament continued to uphold the importance of accession, and on 20 April 2016 the Committee on Constitutional Affairs organized a public hearing on the EU's accession to the Convention and summarized the findings of the EU Court in order to examine ways and means of renewing the accession process. The absence of the EU accession to the Convention issue among the priority areas of the European Commission, ignoring the topic of accession in the Commission work programmes for 2018-2020, EU efforts to implement the Charter of Fundamental Rights of the EU in the EU institutional mechanism put the EU accession to the Convention for Human Rights and Fundamental Freedoms under the question.

Having analyzed the acts of the institutional mechanism of the European Union (the acts of the European Commission and the European Parliament), having raised the issue of accession of the European Union to the Convention, for the period from 2016 to 2020, it was concluded that there is no reason either to object to the relevance for the EU to access to the Convention or claim its active interest in it. On the one hand, the acts of the EU institutional mechanism continue to include provisions on the importance and priority of EU accession to the Convention, and on the other hand, the process of developing legal instruments for establishing EU accession to the Convention models are clearly seemed to be delayed, which cannot but push the views on shifting the EU priorities in the field of human rights protection - from the integration of the existing EU and Council of Europe systems to strengthening of the EU's human rights protection system and enforcing the EU's Charter of Fundamental Rights in it.

Key words: European Union, Convention for the Protection of Human Rights and Fundamental Freedoms, Opinion 2/13, accession, European Commission, European Parliament, Charter of Fundamental Rights of European Union. 